\title{
A História - e o arquivo - em versão Punk: entrevista com Alexandre de Almeida
}

Entrevista por Matheus de Paula Silva e Pedro José de Carvalho Neto Transcrição por Gabriel Yukio Shinoda Oliveira e Pedro Carvalho Silva

Revisão por Gabriel Yukio Shinoda Oliveira, Letícia Oliver Fernandes, Pedro José de Carvalho Neto e Yan Fernando Pereira Catuaba

DOI: 10.11606/issn.2318-8855.v9i2p73-107 


\section{entrevista}

Alexandre de Almeida

Alexandre de Almeida estabelece sua formação moral e intelectual a partir de três pilares que, à distância, nos parecem ter pouca relação entre si: a Igreja Católica, o Escotismo e o movimento Punk. Influenciado por esses grupos, Alexandre cursou História na PUC-SP, se tornou mestre em Antropologia pela mesma universidade e se doutorou em História Social pela USP, com um guia de referência sobre os Skinheads White Power de São Paulo. Nesse mundo tão divergente, o arquivo aparece como sua profissão - e uma paixão.

Nossas leitoras e leitores vão encontrar nas próximas páginas uma trajetória de vida que vai do $A B C$ Paulista à universidade particular e de rádios piratas ao mundo dos supremacistas brancos, passando pela reflexão acerca do mundo dos arquivos, dos documentos audiovisuais e sonoros, da digitalização de documentos e, também, do próprio papel do historiador. Nosso entrevistado não se tornou arqueólogo, como queria no início da graduação, mas a história que nos conta não perde em nada para um filme de Indiana Jones. Como nos adverte Alexandre na última linha de nossa conversa, "Esteja preparado!".

Boa leitura a todas e todos!

Revista Epígrafe: Você pode começar contando para a gente sobre sua aproximação com as Ciências Humanas, sobre o porquê de você ter escolhido História e sobre o que te fez entrar nesse mundo?

Alexandre de Almeida: Bom, primeiro eu quero agradecer a vocês da revista por me dar essa oportunidade de falar. Acho bem bacana trocar essas ideias com vocês. Num dia que eu acho complicado, o dia em que nossa profissão foi vetada pelo 


\section{entrevista}

A História - e o arquivo - em versão Punk

Bolsonaro ${ }^{1}$... Eu fiquei o dia todo pensando nisso, na entrevista, pensando na fala do Bolsonaro. Minha esposa, a Yara Gabriel, também é historiadora e a gente ficou conversando um pouco sobre isso, refletindo sobre os caminhos da profissão, como em tempos de negacionismos dos mais variados possíveis e de coronavírus, o quanto a gente é importante e o quanto esse tipo de grupo nos vê como uma ameaça, o que é uma coisa preocupante, no sentido de alguma retaliação.

Mas como é que eu cheguei às Ciências Humanas? Essa é uma pergunta que me faz pensar na minha própria trajetória de vida. Eu sou filho de professores, minha mãe é professora de Artes e de iniciação musical e meu pai é professor do ensino fundamental e médio de Ciências: Química, Física, Matemática e Biologia. São pessoas que sempre tiveram conexão com a educação. Minha mãe um pouco depois, porque ela só voltou a estudar quando eu estava com 15, 16 anos; quando criança ela só tinha estudado até a $4^{a}$ série, porque na época, segundo a lógica do local onde eu morava - eu sou de Santo André, no ABC Paulista -, a mulher tinha que saber matemática suficiente para fazer as contas da feira e a leitura suficiente para ler a Bíblia e a receita do bolo.... Era uma mentalidade de época, que felizmente estamos superando. Enfim, minha mãe foi estudar, com todas as dificuldades do mundo, com três filhos, e venceu!

Bom, o que vem à minha cabeça, as duas primeiras coisas que fizeram eu me interessar por História: era a coleção de enciclopédias do meu pai - eu brincava que era a internet da minha época. Meu pai tinha a coleção completa da Barsa, uma enciclopédia chamada Conhecer e outra muito legal sobre a iconografia da História do Brasil. Então, eu passava horas lendo a Barsa, lendo a Conhecer, e aquilo foi instigando um pouco o gosto por História. É interessante que nem foi tanto pelo

\footnotetext{
${ }^{1}$ Entrevista realizada no dia 27 de abril de 2020, dia em que o presidente Jair Bolsonaro vetou a lei que regulamentaria a profissão de historiador. O veto foi derrubado em 17 de agosto de 2020.
} 


\section{entrevista}

Alexandre de Almeida

ensino fundamental, eu até curtia História, mas minha entrada principal foram essas enciclopédias. E aí na escola eu conheci gente que tinha os mesmo hábitos, porque anos 1960 e 70, até os 80, a cultura da enciclopédia popular (vendida nas bancas de jornal, em fascículos) era muito forte, então acabei montando um grupo de amigos, que seriam hoje os nerds, e ficávamos discutindo coisas que víamos nas enciclopédias.

Duas outras coisas que me chamaram muito a atenção nessa minha reflexão sobre como eu cheguei às Ciências Humanas é que meus pais sempre foram ligados a movimentos sociais da Igreja Católica. Meu pai e minha mãe eram ligados às comunidades eclesiais de base, que é um movimento ligado a Teologia da Libertação e, por muitos anos, a infância e a juventude toda, a gente participava de grupo de jovens na Igreja, viajava muito, tinha muita discussão sobre problemas sociais, nada muito aprofundado, na linguagem dos adolescentes, mas havia sempre esse estímulo. Sempre tinha muita gente em casa, debate de grupos da Juventude Operária Católica, da Juventude Universitária Católica falando sobre política em um momento de transição do regime autoritário e para a democracia.

E uma terceira entrada, muito importante, acho que até mais importante do que as outras duas, foi, acreditem, o Escotismo. Dos 7 aos 25 anos eu frequentei religiosamente o grupo de escoteiros - até hoje vou e me considero membro do movimento; foi uma experiência muito interessante, porque ao mesmo tempo que se conhece muita gente diferente, você viaja bastante, você é instigado também a ter "espírito aventureiro", de querer fazer e conhecer coisas novas.

Uma quarta via é o convívio no movimento Punk. O contato com a música foi uma entrada muito legal, de conhecer bandas de tudo quanto é canto do mundo e as suas demandas, me fazia pensar na minha realidade. Às vezes o pessoal chegava com 


\section{entrevista}

A História - e o arquivo - em versão Punk

fita cassete e dizia: "isso aqui é uma banda... da Finlândia.", "Putz, mas da Finlândia?", "Tem Punk na Finlândia?", "O que eles pensam?' e por aí vai.

Enfim, circulei por diversos ambientes que estimularam esse gosto por conhecer História; depois eu conheci áreas afins, como Antropologia, Arquivologia, etc.... Mas, na verdade eu queria ser veterinário, porque na minha realidade fazer História era sinônimo de ser professor do ensino fundamental básico na rede pública ou em algumas das poucas escolas particulares em Santo André. Enfim, o "caminho do sucesso" era esse: fazer Direito, Medicina, Administração, Veterinária, Odontologia, etc...

Eu lembro muito da minha avó materna falando isso, não desse jeito, mas com essa ideia, de profissões de manutenção da família. Ela ficava super feliz porque eu ia cuidar dos cachorros, dos gatos e dos passarinhos do meu avô, na condição de veterinário. Até prestei o vestibular de Veterinária na USP, mas não passei. E, um ano, mais ou menos, um ano e meio depois, meu pai aposentou e falou: "vou prestar o vestibular para Medicina, vamos lá, vamos prestar também?", "Ah, vamos, mas eu vou prestar para História". Prestei, passei e fui para a PUC [Pontifícia Universidade Católica de São Paulo] e como diz a música do Zeca Pagodinho, "ela é particular", né? A primeira coisa que chocou era o valor da mensalidade, muito cara, e eu lembro meu pai, que tinha acabado de se aposentar, dizendo: “Não, pô, eu vou mantendo a mensalidade e vamos correr atrás de bolsa, mas não para de estudar, continua!". Eu e meus irmãos sempre tivemos muito incentivo para estudar. Lembro-me que passaram seis meses, estou falando de julho de 1993, e abriram inscrições para o Crédito Educativo, que foi substituído na gestão do FHC pelo FIES. Pensei: “É isso! Como consigo essa bolsa?" E aí me disseram na PUC-SP que era uma bolsa de 80\% e não precisava de fiador. Só assim consegui terminar a graduação. 


\section{entrevista|}

Alexandre de Almeida

Mas essa não foi a única dificuldade de vencer, havia outras, como a grana para tirar xerox, uma constante em diversas gerações de estudantes. A grana da alimentação, a grana para o transporte, enfim, uma série de dificuldades financeiras a serem vencidas. E como é que você vai conseguir grana no primeiro ano de faculdade, e que tipo de emprego você vai executar? Ser professor substituto na educação básica. Então eu lembro que, foi até divertido, porque minha mãe morria de medo que eu fosse dar aula, pois me achava muito bravo, que as crianças iriam ficar assustadas comigo e coisas assim do tipo, mas apoiou.

Minha primeira turma foi uma quinta série, durante um mês, e quando acabou esse mês de aula a coordenadora me chamou, falou que eu tinha muito que aprender, apontou minhas dificuldades e os erros de principiantes. E eu falei: "Sim, estou aprendendo, meus pais são professores e a gente sempre conversa muito". Daí ela perguntou: “Quem que são seus pais?", “É o Cláudio e a Clarice,". Aí, ela falou: “É a Clarice Gomes?". Ela era amiga da minha mãe e só fiquei sabendo depois de quase um mês. Por fim, ela acabou me indicando para outra escola.

Eu dei aulas no meu bairro para as pessoas com quem eu convivia, algumas situações eram engraçadas. No meu primeiro dia de aula, na segunda escola em que trabalhei, para o terceiro ano do ensino médio, lembro que era uma sexta-feira, e a gente tinha marcado um show de Hardcore, senão me engano em Ferrazópolis, que na época era uma quebrada de São Bernardo, e ninguém queria levar o meu instrumento. Eu toco contrabaixo. Então, eu fui lecionar paramentado de Punk, com o instrumento, e todo mundo perguntou o que eu estava fazendo ali, se eu não tinha passado na faculdade; eu respondi que sim, passei, e que seria o professor de História. Havia um respeito mútuo e foi um período muito interessante.

Divido a minha carreira de professor entre essa primeira etapa e a atual, a primeira foi de aprendizado. Eu fiz muita besteira, muita "bateção de cabeça", não no 


\section{entrevista}

A História - e o arquivo - em versão Punk

sentido de destratar as pessoas ou ser mal-educado, mas no sentido da própria dificuldade de aprender o que é ser professor. Como você olhar para o outro e falar: o outro tem dificuldades reais, ele não está mentindo para mim. Eu me lembro de outro exemplo que me impactou bastante, quando um aluno me chamou de canto e falou: "professor, eu tenho uma dúvida aqui, eu acho que engravidei minha namorada, o que eu faço?"; "sei lá o que você faz...", pensei. E é isso que me impactou bastante, porque você vê que a vida de professor não é só tratar de um conteúdo, é tratar de gente. É preciso gostar de gente, como dizia Paulo Freire. E eu gosto.

A terceira escola em que trabalhei era localizada em Mauá, no bairro Sônia Maria, trabalhei com a Educação de Jovens e Adultos, também foi muito bacana trabalhar com a EJA. Percebi que não adianta encher a lousa de informação se o cara mal sabe ler. Era o caso do "seu" Domingues. Isso foi em 1994, ele não conseguia ler e o meu trabalho era "despejar" conteúdo em cima dele. Um dia, os professores mais antigos da escola decidiram dar ênfase à alfabetização. E foi aí que eu aprendi que o conteúdo pode ser deixado de lado, aliás, deve ser deixado de lado! Por mais que "fure o planejamento pedagógico" - essa é a expressão que se usa para não focar nos reais problemas de uma escola -, eu tinha uma demanda mais importante: um cara que não sabia ler, trabalhava o dia inteiro numa profissão braçal e ficava sofrendo na escola das 19 às 22h30 porque não estava entendendo nada. Foi um desafio e é uma discussão que precisamos aprofundar na formação de professores.

Nesse meio tempo, na faculdade, havia outra dificuldade, que todo mundo já vivenciou: compreender as leituras, em especial as mais teóricas. Aquele texto que te passam para a semana seguinte, você começa a ler, pega o dicionário e vai lendo, chega depois de algumas horas você não entendeu e relê de novo e vai sentindo a dificuldade de compreensão e a frustração. Eu me sentia o próprio "seu” Domingues. 


\section{entrevista|}

Alexandre de Almeida

Coisas legais também aconteceram e, mais uma vez, eu conheci muita gente, convivi com muita gente. E a PUC-SP, embora seja uma universidade particular, na minha época de estudante tinha gente muito, muito rica, que morava em triplex em Santo Amaro - eu nunca tinha ido a um triplex até aquele momento. Algumas colegas juntaram a grana e foram passar as férias em Roma para estudar antiguidade clássica, pois era uma galera que tinha uma grana e sabia fazer bom proveito dela. Tinha gente que era de classe média, como no meu caso, e tinha gente que era muito, muito pobre, a ponto de a gente fazer vaquinha para bancar a passagem de ônibus da pessoa. Não tinha disputa entre os estudantes, todo mundo se dava muito bem, salvo um ou outro, mas de modo geral o convívio era muito bom.

Revista Epígrafe: Teve disciplinas voltadas para o ensino de História, uma vez que você foi professor?

Alexandre de Almeida: Pelo regimento da época eu só poderia começar a fazer as disciplinas de licenciatura a partir do quinto semestre, ou seja, a partir do terceiro ano. Muita gente que também pegou aula como professor temporário sentia dificuldade com questões mais básicas sobre ser professor, sabe? Essa é uma questão bastante comum. Enfim, eu só fui fazer as disciplinas de licenciatura em 1998 e 1999, mas ao longo dos primeiros anos era o bacharelado clássico.

Na licenciatura, tínhamos as disciplinas tradicionais como Sociologia da Educação, História da Educação, etc... A que mais me impactou foi o estágio supervisionado, com a professora Ana Maria Furtado. Ela trabalhou a vida toda na educação básica pública e tinha muita experiência sobre como lidar com os estudantes e a postura ética do professor. 


\section{entrevista}

A História - e o arquivo - em versão Punk

Revista Epígrafe: Como foi o TCC [Trabalho de Conclusão de Curso]?

Alexandre de Almeida: Meu TCC foi sobre as bandas de Skinheads White Power paulistas. Eu já tinha algum conhecimento anterior sobre esse tema, por causa do movimento Punk. Nesse meio circulavam não só informação sobre o anarquismo, mas circulavam também informações sobre o "inimigo". Então, antes de entrar na universidade, eu já tinha essas informações. O tema gerou um debate muito interessante, pois ainda há aquela ideia de que você é militante do seu tema de pesquisa, o que não era o caso, mas apesar disso, a proposta foi bem acolhida e foi aí que comecei a trabalhar com documentos sonoros, no caso, as canções.

Outro episódio importante na minha trajetória de pesquisador, ainda na graduação, foi a aula magna. Para nós do primeiro semestre, foi da professora Márcia Regina da Costa, do departamento de Antropologia, sobre seu livro chamado Os carecas do subúrbio: cominhos de um nomadismo moderno, tratando de um grupo Skinhead da zona leste, fruto de sua tese de doutorado, defendida em 1992. Nessa época eu conheci o César Campiani, um grande amigo, que também era ligado ao Punk, e decidimos ir conversar com ela. A reação dela foi mais ou menos assim: “nossa, que legal, vocês são Punks, poxa vamos fazer iniciação científica, vamos estudar, vamos trabalhar esse assunto". A gente queria falar sobre quem ela entrevistou, enfim, e ela falando sobre usar nossa experiência para fazer um TCC, fazer um mestrado. Estávamos no primeiro semestre e ela já falando em mestrado...

Comecei a participar de alguns eventos que ela desenvolvia com um grupo de estudos sobre juventude e sociabilidade urbana e foi nesse momento que comecei a alinhavar o que seria o mestrado. Na verdade, eu queria fazer mestrado na História, mas não rolou, não teve abertura, enfim, não deu certo. A Márcia fez a pesquisa dela indo até a casa dos "Carecas do Subúrbio", indo até os shows, porque a Antropologia 


\section{entrevista}

Alexandre de Almeida

exige muito trabalho de campo e sentia que esse era um caminho interessante para a minha pesquisa. Eu já tinha começado a montar meu acervo particular, porque não tinha muita documentação em arquivos públicos e nem no CEDIC [Centro de Documentação e Informação Científica da PUC-SP]. Nesse último havia muito material sobre o movimento Punk, mas sobre o grupo que estudava tinham poucos documentos.

Fiz o TCC no final da década de 1990 e comecei o mestrado dois anos depois, de uma forma inusitada. Em 2000, houve o lançamento da segunda edição do livro da Márcia, aí pensei: “poxa, será que eu tenho essa segunda edição?". Tinha me tornado um colecionador voraz. E lá vou eu até a PUC, lá no quinto andar, onde seria o coquetel de lançamento. Foi bate pronto! Eu cheguei, ela me viu do outro lado do corredor, veio conversar comigo e falou: “E aquele seu trabalho?". A gente sentou, conversou, tenho até a fita que gravei com nossa conversa, e ela me emprestou uma pilha de livros e disse: "Isso daqui é a bibliografia que vai cair na prova. Eu sei que você está sem grana, porque não dá para tirar xerox, então tá aqui. Você usa e me devolve depois quando tiver passado na prova". E essa foi a minha entrada na Antropologia.

Nesse meio tempo, da graduação para o mestrado, lembro que fui em um show em Santo André, não me lembro agora, acho que foi da banda Inocentes, uma banda de Punk Rock e encontrei um cara do escotismo, o Renato. Ele falou: "estou trampando em uma rádio em Santo André, você não quer trampar lá?"; eu falei: "ah, paga?"; ele: "paga sim, não é trabalho voluntário não, é uma grana que você ganha". Aí fui lá, fiz um teste, entrei, trabalhei dois anos em uma rádio que, eu sempre brinco, era uma rádio livre e o Ministério das Comunicações dizia que era uma rádio pirata mas era uma rádio pirata mesmo... [risos]. Mas era uma rádio muito interessante, porque ela era focada em Rock'n'Roll, seu nome era Patrulha FM 91.7, tinha o slogan 


\section{entrevista}

A História - e o arquivo - em versão Punk

"sua rádio rock no $A B C "$ e havia um forte trabalho de prestação de serviços. Havia programa com gente do Procon [Fundação de Proteção e Defesa do Consumidor], com gente da UNE [União Nacional dos Estudantes], da UMES [União Municipal dos Estudantes Secundaristas de São Paulo]. Sempre tinha gente fazendo prestação de serviço e divulgação da cena musical local.

Revista Epígrafe: Aproveitando o gancho da entrada na Antropologia, como foi essa passagem para outra área?

Alexandre de Almeida: No meu caso acho que foi tranquilo, porque eu já tinha esse contato com a Antropologia na graduação, já tinha as disciplinas e já conhecia a professora, sabia do trabalho dela. Eu achei que fiz o certo de ter ido para outra área, porque - é o que eu acho, não é o que todo mundo deve fazer - pelo menos o mestrado deveria ser em outra área. No doutorado você pode voltar para a mesma área, mas pelo menos um mestrado ou pelo menos fazer disciplinas como aluno especial em outras áreas. Para mim foi muito importante isso, metodologicamente falando, conhecer outra linha teórica que se casa com a História, de conviver com pessoas que pesquisam outros temas. Na PUC, era muito forte na época a pesquisa sobre Brasil Republicano, mas na Antropologia tinha muita gente pesquisando Hip Hop, gente pesquisando Punk Rock, eu pesquisando Skinhead White Power, uma moça que pesquisava grupo de extermínio, outra que pesquisava jogo do bicho. Então foi assim, um arejamento, uma abertura de horizontes muito importante.

Na minha época as pessoas faziam a graduação em História, iam para o mestrado, eram os mesmos professores, eram as mesmas pessoas, alguns estudantes de fora também, mas o que eu quero dizer é que ficava no mesmo núcleo. Na Antropologia, tinha eu que era da História, gente do Jornalismo, da Educação 


\section{entrevista}

Alexandre de Almeida

Física, da Fotografia, etc.... Essa pessoa da Fotografia me marcou muito também porque a dissertação de mestrado dela foi um ensaio fotográfico, com uma introdução, claro, explicando todo o processo, mas foi um ensaio fotográfico. Isso foi muito marcante para mim também. Acho que isso, de certa forma, acaba até influenciando no meu doutorado, mas acho que em linhas gerais é mais ou menos isso.

Revista Epígrafe: Como se deu a escolha do tema do seu mestrado?

Alexandre de Almeida: Eu entrei na universidade com 21 anos de idade, querendo ser arqueólogo, obviamente por causa do Indiana Jones, de quem sou fã. Aí eu procurei o Museu de Arqueologia e Etnografia da USP; telefonei de um orelhão, não tinha internet nem celular na época, peguei o número na lista telefônica, liguei para um professor e ouvi o seguinte: “olha, aqui a gente não tem bolsa, você precisa trabalhar voluntário uma época e depois a gente tenta uma bolsa". Não rolou. Eu precisava de grana para sobreviver, não deu certo e não o procurei mais.

Depois de um tempo, pensei em pesquisar outras coisas: o escotismo, pensei em pesquisar a Revolução de 1932, tentando novamente a área de Arqueologia, mas acabou não dando certo também. E aí, como eu falei, nesse meio tempo mantive contato com a Márcia e ela sempre falava: "você tem um tema muito legal em suas mãos, você tem uma discussão bastante interessante e, vira e mexe, na imprensa fica aparecendo as barbaridades que alguns desses caras acabavam fazendo nas ruas", você precisa falar sobre isso. Daí tomei a decisão, fui para a Antropologia. Foi do meu gosto, eu não escolhi o tema só para ter o título. Fui porque realmente gostava do tema. A gente não pode - comigo não foi assim - entrar em uma graduação e pensar: “bom, minha vida acadêmica já está programada, já sei o que eu quero estudar no 


\section{entrevista}

A História - e o arquivo - em versão Punk

doutorado". Não, não é assim; a construção ao longo do caminho é mais importante que objetivo final.

Bem, aí, eu fiz o mestrado. Foi bem divertido, as discussões nas Ciências Sociais são muito bacanas. Fazer a pesquisa de Antropologia é ir para campo, encontrar, conversar com as pessoas, o inesperado... Você pode chegar ao local da entrevista, como já aconteceu, a pessoa senta de boa, abre uma cerveja e começa a conversar; como você pode ir até o local de trabalho de campo e não ficar muito tempo ali, porque alguém não gostou de você, achou que você está espionando e coisas assim do tipo.

Mas, enfim, fiz o mestrado; em 2004 eu defendi, já tinha engatilhado o doutoramento na Antropologia mesmo, mas parei um pouco por causa do trabalho. Participava de alguns eventos que a Márcia promovia, conversava com ela de vez em quando. Mais ou menos lá para 2007, a gente voltou a ter um contato mais próximo para desenvolver o doutorado. Eu lembro que nós fizemos um trabalho de campo juntos, fomos a uma igreja localizada no Copan onde aconteciam shows de um movimento cristão chamado Christian Metal Force, eram bandas de Heavy Metal, Punk Rock Hardcore e Reggae, todas cristãs e ligadas à Igreja Renascer em Cristo. Então, nós fomos até a esse evento e foi lá que eu descobri que ela estava bem doente. Depois disso, fizemos uma reunião em sua casa e depois de uns três meses eu recebo a notícia de que ela tinha falecido. Eu lembro que o mundo desabou, ela era uma mãe acadêmica para mim. Isso em 2007, e eu pensei: “ah, se não dá para fazer com ela, não vou fazer com mais ninguém", dada a importância que ela teve para a minha formação e até na minha própria vida, porque o mestrado de Antropologia me ajudou muito a abrir a cabeça para tudo, me ajudou muito a fortalecer a conduta de não ser uma pessoa preconceituosa. Já tinha essa formação na igreja, na família, no escotismo, mas isso também mexeu comigo. A universidade 


\section{entrevista|}

Alexandre de Almeida

não mexe com a gente só no campo da produção intelectual, mexe também com a nossa conduta.

Revista Epígrafe: Seu doutorado é um guia de referência, um trabalho pouco comum na História. O que isso significa e quais as vantagens desse tipo de trabalho?

Alexandre de Almeida: Em 2010 pensei: “bom, eu vou voltar a produzir academicamente, escrever artigo, ir a eventos". Em um sentido de homenagem, de tributo que a Márcia merecia. Eu tinha na minha cabeça algo do tipo: ela não despendeu tanto tempo da vida dela para me orientar, para morrer por aqui, para eu parar por aqui. E aí, eu tive uma conversa em 2010, num encontro de pesquisadores do Integralismo, que aconteceu em Juiz de Fora com outro grande amigo meu, que é o Renato Dotta, e ele falando: "e aí meu, e o doutorado?"; “ah, não sei, eu gosto de História, eu gosto de Antropologia, eu gosto de Arquivos, eu gosto de música". E ele disse o seguinte: "ah, meu, você vai ter que escolher alguma coisa". Olhou para a minha cara e deu uma risadinha: "ou você mistura tudo". Eu falei: "eu vou misturar tudo. Não sei quem vai me orientar nisso, mas eu vou misturar tudo". Eu já trabalhava na Fundação FHC [Fernando Henrique Cardoso], e lá eu tenho contato com a professora Ana Maria de Almeida Camargo, que é consultora da Grifo Projetos Históricos, e a gente se conhecia desde 2000. Aí, um belo dia, isso foi em 2010, 2011, conversando com a Ana Maria, ela falou: "por que você não faz um guia de referência dessas bandas que você coleciona desde a época do TCC?". Pronto, misturou, deu certo, consegui misturar. E a Ana Maria topou orientar e também considero outra pessoa fundamental, uma verdadeira mentora na minha vida acadêmica. O que mais me marcou na relação com ela foi o apoio irrestrito em orientar um tema "duro" como o relacionado a extrema direita, mas, também, a generosidade e proposta de 


\section{entrevista}

A História - e o arquivo - em versão Punk

um trabalho pouco convencional, mas de grande relevância para o estudo das direitas.

Bom, a gente está acostumado na academia àqueles formatos mais tradicionais de tese e dissertação e quando a gente pensa nesse... Eu estou falando de certo senso comum, não é determinante na universidade, mas quem trabalha na área de documentação, uma vez na vida já ouviu que esses tipos de instrumentos seriam "algo menor" na produção acadêmica, quando, na verdade, são instrumentos importantes, porque sem eles não tem pesquisa. Eu trabalho na área documentação há um tempão, então isso está muito claro para mim; sem esses instrumentos a pesquisa fica inviabilizada. É preciso pesquisadoras e pesquisadores seniores desenvolvendo esses trabalhos, porque senão a gente inviabiliza a pesquisa nos acervos.

Ao longo desses anos fui montando um acervo particular com documentos produzido pelos Skinheads White Power aqui de São Paulo e muita coisa de fora também. E quando eu falo de Skinheads White Power, eu vou só dividir, porque é um termo polissêmico: existem skinheads que são White Power, supremacistas raciais brancos; skinheads comunistas e anarquistas; existe uma vertente de skinheads gays. Skinhead, na verdade, é um estilo, é uma subcultura que não necessariamente está vinculada a um discurso político único; o mesmo vale para o Punk, existem Punks de esquerda e de direita; a mesma coisa vale para o Rap, tem de esquerda e de direita.

Então veja, esse guia de referência, em primeiro lugar, mais do que dizer para a gente quais são as bandas Skinheads White Powers que existem aqui no Brasil, quais são seus repertórios, quais são as organizações às quais eles estão vinculados, é uma discussão para dizer que há uma diversidade de grupos nessas subculturas, que merecem uma atenção, que merecem uma pesquisa "feita com a lupa". Então esse 


\section{entrevista}

Alexandre de Almeida

guia de referência abarca essa discussão, nem todo skinhead é White Power, como nem todo punk é de esquerda. São alguns sensos comuns que rodam ali.

Segundo, o guia de referência é a organização do meu próprio acervo para fornecer ao pesquisador todo o repertório que foi produzido por essas bandas; e, terceiro, com uma metodologia que vem da área de arquivos, discuto um conceito chamado tipologia documental, ou seja, em linhas bem gerais, procuro atribuir "nomes aos documentos", segundo a função para a qual ele foi criado. Na área de arquivos, quando a gente fala de canções, essa é uma discussão muito incipiente, precisa de mais gente discutindo, pois como descrevê-las em um banco de dados? Eu vou dizer que tudo é música? Que tudo é canção? Enfim, se eu tenho que produzir um instrumento de pesquisa, é preciso evitar a criação de grandes categorias genéricas. $\mathrm{E}$ como é que eu faço isso com as canções? Eu comecei a analisar as canções, as letras delas e bater com a documentação produzida por essas organizações. Aí eu criei algumas categorias de canções inspiradas no nosso trabalho lá na Fundação FHC em relação às cartas. Cotejando a minha documentação, pensei: “eu tenho canções de denúncia aqui", denúncias na percepção desses grupos.

Esses grupos têm alguns elementos estruturantes que é legal a gente colocar aqui. Um deles é a defesa da supremacia do branco, muito calcada no discurso cientificista do século XIX, aquela ideia da hierarquização das raças. Outro elemento estruturante muito forte nesse meio é a conspiração dos judeus, também, retomando essa discussão sobre o mito da conspiração judaica; há um discurso anticomunista muito forte; há um discurso pró regime autoritário, a secessão do estado de São Paulo, pró ditadura militar; negação do Holocausto; há também, agora mais recente, um discurso islamofóbico muito forte. Então, eu fui percebendo que esses grupos trabalham no campo da metapolítica, onde se tenta ganhar os “corações e mentes das pessoas". Em outras palavras, a metapolítica procura mostrar para as pessoas 


\section{entrevista}

A História - e o arquivo - em versão Punk

outra cosmovisão e convencê-las de que essa cosmovisão é a mais adequada e para isso os grupos se utilizam da música, porque essa cosmovisão é endereçada a fãs de música e, portanto, a ideia é utilizá-la como ferramenta.

Então eu fui percebendo nos artigos acadêmicos e nas publicações dos próprios grupos possibilidades de atribuir funções às canções. Por exemplo, lendo o livro Os protocolos do sábio do Sião, um clássico do mito da conspiração judaica, produzido durante o regime do último czar russo e eu percebia trechos do texto presentes na canção. Como o texto e a canção tem como finalidade "denunciar" a suposta conspiração judaica, pensei em nomear essa canção como "canção de denúncia".

Em suma, minha proposta foi criar um instrumento mostrando o repertório das bandas Skinheads White Power, mas percebo que posso fazer o mesmo com bandas Skinheads de esquerda a mesma coisa com o Rap de São Paulo ou dos Estados Unidos, então esse é o primeiro movimento. O segundo movimento é que, essas canções, elas têm funções, a música é importante na luta política desses grupos e as canções cumprem funções pedagógicas, para identificar o inimigo, no caso das "canções de denúncia"; para exaltar os heróis, no caso das "canções de homenagem"; para motivar as pessoas, no caso das "canções da motivação"; temos também canções que criticam condutas, aquele militante que se vinculou a um grupo e depois abandonou e assim por diante.

A vantagem nesse tipo de trabalho é a seguinte: eu consegui juntar tudo o que eu curtia, porque eu consigo contar a história do Skinhead White Power aqui no Brasil, as suas diversas organizações em ordem cronológica; eu fiz uma abordagem antropológica, porque eu falei de um segmento da subcultura Skinhead; eu consegui trabalhar na área de arquivos, consegui fazer um instrumento de pesquisa que pode ser útil para muitas pessoas; e o quarto e último ponto, que foi muito legal, é que me 


\section{entrevista}

Alexandre de Almeida

vi obrigado a voltar a estudar música, pois alguns elementos da musicologia aparecem no instrumento de pesquisa. E sobre esse último ponto conto uma história interessante.

Durante a qualificação - quem participou da banca foi a Sonia Troitiño [Rodriguez], a professora Maria Aparecida de Aquino e a professora Ana Maria de Almeida Camargo - foi a seguinte: "Alexandre, você está falando de trabalhar com música, mas aqui nesse momento você está falando muito mais da letra. E a música? Quer dizer, a parte musicológica do documento, você não vai abordar?". Foi até engraçada a situação. "Se você não abordar, não tem problema, vamos só trabalhar com as letras, mas se você abordar, será mais interessante". Eu lembro que eu "enchi a boca" e falei: "Mas é claro que eu vou trabalhar com as músicas, mas é claro...". E assim que acaba a qualificação eu me pergunto: "o que fui dizer?", "por onde que eu começo?"... [risos]. São os caminhos por onde a vida nos leva.

Nessa época eu lecionava na FMU [Faculdades Metropolitanas Unidas], no curso de Ciências Sociais e no curso de História. Eu tinha muito contato com o pessoal da Música e fui conversar com eles. Falei: “Olha, eu tenho um trabalho assim e assado, e eu queria na verdade levantar os elementos referentes à música passíveis de serem colocados em um instrumento de pesquisa". Só para a gente exemplificar: tonalidade da canção, o padrão rítmico, a forma musical. etc.... São elementos que estão na canção, que eu consigo identificar, consigo criar grupos e consigo agrupá-los de acordo com as suas proximidades para desenvolver termos pesquisáveis. A primeira coisa dita foi: “Não, isso daí é Rock, é só efeito"; “a gente não trabalha com Rock aqui, você vai ter que conversar com uma professora chamada Marisa Ramires", professora de teoria musical.

Fui conversar com ela, levei um CD como exemplo, ela tirou quase o CD inteiro no piano, de uma vez só. Pensei: "Putz, resolvido o problema, é com ela mesmo". 


\section{entrevista}

A História - e o arquivo - em versão Punk

Fiquei feliz. Mas ela falou: "Não sei te ajudar com isso aqui, isso aqui é Rock". Estava quase ligando para a Ana Maria para falar: “Ah, vai ser só análise de letra mesmo, ferrou."... [risos]. Mas professora Marisa me indicou dois estudantes dela, o Alexandre Ório, que tocava em uma banda de Heavy Metal, chamada Claustrofobia, e o Heraldo Parmaan, que toca profissionalmente desde os 17 anos de idade (hoje tem 52), é mestre em guitarra elétrica no departamento de música da UNESP e teve uma passagem no Ultraje a Rigor. Ele acolheu a minha ideia, falou: "vamos estudar música". Isso implicou em estudar o repertório, tirar o repertório inteiro no contrabaixo, que é o meu instrumento, depois no violão, para transformar as informações em dados para compor um vocabulário controlado.

Então veja, tem um desafio e eu sinto muita gratidão à Ana Maria Camargo por isso, porque não foi uma professora que disse: “não, corta aqui, não precisa se preocupar com isso". Pelo contrário, ela falou: "não, vamos juntar tudo isso que você sabe e vamos em frente". Não saiu um trabalho perfeito, obviamente, nem me preocupei tanto com isso, para não ficar amargurado e ansioso, mas a Ana Maria também é a minha segunda "mãe acadêmica", ela acolheu a minha ideia, ajudou a melhorar; a ideia do guia de referência foi dela. Faz pouco tempo que defendi, 2017, mas desde então, as devolutivas são as melhores possíveis. Foi bastante satisfatório poder aproveitar toda essa experiência acumulada e chegar nesse resultado. Acho que o doutorado, ele tem essa característica, ser um momento não só de maturidade acadêmica, mas de você poder fazer uma avaliação da sua vida, olhar para tudo o que você passou e tudo o que está presente.

Revista Epígrafe: Acho que a gente pode entrar já na questão dos arquivos para você falar um pouco sobre como você entrou nesse mundo, sobre os seus primeiros trabalhos, e daí a gente entra numa questão mais teórica sobre os arquivos. 


\section{entrevista}

Alexandre de Almeida

Alexandre de Almeida: Bom, como eu falei, em 1995, eu lecionava em escola estadual, mas não estava contente, achava que não estava indo bem e eu já tinha interesse em museu, especificamente no Museu Paulista. Era um museu que eu visitava desde moleque, era um museu bonito, era a referência que eu tinha de museu. E como eu me deslocava de trem desde Santo André para faculdade, passava sempre na estação Ipiranga. Então comecei a pesquisar na faculdade como eu poderia trabalhar nessa área de patrimônio e aí me indicaram a FUNDAP [Fundação de Desenvolvimento Administrativo], que era uma fundação que dava bolsa de estágio para estudantes de graduação.

Aliás, um pouquinho antes da FUNDAP, eu ia até o Museu Paulista para conversar com a professora Margarida [Davina Andreatta], porque ela tinha um trabalho sobre arqueologia industrial. Nessa época, pensei em pesquisar a arqueologia da Revolução de 1932, porque, como meu pai tinha sítio em Monte Sião e lá ocorreram combates, eu tinha acesso às trincheiras; tinha acesso aos museus das cidades onde foram encontrados os artefatos dos campos de batalha e a excombatentes. Quando eu fui até a FUNDAP, eles só tinham vaga para estagiário no Museu Paulista na área de iconografia, com as professoras Solange Ferraz de Lima e a Vânia Carneiro. Aí conversei com a professora Margarida, enfim, não deu certo continuar na área de arqueologia. Novamente tinha o aspecto da grana, porque era uma grana que ia me ajudar a terminar a graduação e lá fui eu trabalhar com as duas, foi um estágio muito interessante. Eu trabalhei com os negativos de vidro do acervo Militão Augusto de Azevedo. Foi meu primeiro trabalho: higienizar negativos de vidro. Foi muito legal. Por questões pessoais, acabei não aproveitando o estágio por completo, mas foi a minha primeira experiência profissional de uma instituição custodiadora de acervos e devo muito à Solange e à Vânia pela oportunidade. 


\section{entrevista|}

A História - e o arquivo - em versão Punk

Depois disso, eu consegui um estágio pelo CIEE [Centro de Integração EmpresaEscola] no museu do BANESPA [Banco do Estado de São Paulo]. Em paralelo, desde a época do Museu Paulista, eu estagiava também no Memorial da América Latina. Depois, teve a época que fiquei dois anos trabalhando com rádio, e aí, no segundo semestre de 1999, eu estudava com a Yara Gabriel e ela me avisou que estavam precisando de gente no setor de "arquivos especiais" do Arquivo Público do Estado de São Paulo. Eu fiquei lá de 2000 até final de 2004, e foi a minha "faculdade" de arquivologia. Acho que muita gente que passou por lá vai concordar comigo, porque ali a gente aprendeu o que é trabalhar em arquivo. Ali eu já não era estagiário, eu era funcionário e um ano e meio depois coordenava setor. Lá eu conheci o pessoal da ARQ-SP [Associação de Arquivistas de São Paulo] e fiz todos os cursos que eles ofereceram, com bolsa, pois éramos funcionários da casa.

Depois de um tempo, eu estava querendo sair do Arquivo do Estado, buscando outras oportunidades interessantes. Na verdade, eu queria circular por outros tipos de arquivo. Eu estava em arquivo institucional, público, embora trabalhando com documentação privada, do jornal Última Hora, do jornal Movimento, do jornal Aqui São Paulo. Tinha também o "Memorial dos Governadores", formado pelo acervo do Washington Luís, do Macedo Soares, do Altino Arantes, do Adhemar de Barros, etc... Mas eu queria circular. E aí, em 2004, houve um evento lá na Fundação FHC sobre arquivos pessoais de pessoas públicas, e lá que me "cantaram a bola" que o Centro de Memória Bunge precisava de funcionários. Naquele dia, com a o apoio da Ana Célia Navarro, consegui a oportunidade. E lá vou eu trabalhar no Centro de Memória Bunge, mudando absurdamente de um cenário para o outro.

Lá era corporação, lá tinha uma forma de você brigar pelo arquivo muito diferente do que existia no Arquivo do Estado. Quem trabalha em arquivo privado, especialmente os corporativos, sabe disso. É constante essa necessidade dos 


\section{entrevista}

Alexandre de Almeida

resultados. E apresentávamos bons resultados, com reconhecimento das pessoas que nos pediam pesquisas. Mas, como eu falei, me impactou muito essa mudança para mundo corporativo, a ponto usar paletó, gravata, cabelo penteadinho... [risos]. As meninas com quem eu trabalhava também, todas usando salto alto, maquiagem, super elegantes e profissionais. Mas o que me impactou muito foi ver como a História pode e deve ser presente em qualquer instituição, ver como ela faz a diferença. Mesmo o pessoal mais antigo não conhecia a História da sua própria empresa. Foi uma experiência muito legal, mas eu queria mais, queria continuar vasculhando as possibilidades de atuação do historiador nos arquivos.

Por volta de 2005, a Yara Gabriel trabalhava com a Silvana [Goulart], outra pessoa a quem devo muito e também considero uma mentora. Um belo dia, cheguei para a Silvana falando que eu queria trabalhar com ela. Aí, ela disse que eles estavam precisando de alguém lá na Fundação $[\mathrm{FHC}]$, que tivesse experiência com audiovisual. Respondi: “Bom, eu tenho experiência do Centro de Memória Bunge, tenho experiência com os comerciais, com os jingles, entrevistas, etc...". Então ela me disse que eles precisariam de alguém que também tivesse formação na área de Ciências Sociais, por causa da formação de Fernando Henrique Cardoso (Sociologia) e Ruth Cardoso (Antropologia). Aí, eu disse: “Eu tenho mestrado em Antropologia, serve?". Ela, rindo, então disse: “Ah, eu vou ter que te contratar então, pelo jeito?"... [risos]. Deu certo e trabalho na Grifo Projetos há 15 anos. Também é uma experiência sensacional, uma outra escola profissional. A gente não fica só no trabalho de identificações dos documentos, mas também na difusão, produção de eventos, conversamos com outras as áreas da instituição para compreender como podemos potencializar a documentação do acervo nas atividades cotidianas. Agora, também existe a oportunidade de lecionar em oficinas sobre arquivos audiovisuais e sobre a 


\section{entrevista}

A História - e o arquivo - em versão Punk importância dos arquivos para o ensino médio, como parte do nosso projeto de devolutiva social. Enfim, estou muito feliz com o que eu faço e com quem eu trabalho.

Revista Epígrafe: E quando você cursou a faculdade, você acha que o curso de História te preparou para trabalhar em arquivo? E como você vê também o papel da sua carreira acadêmica em sua vida como documentalista?

Alexandre de Almeida: Bom, como eu falei, a graduação era um bacharelado voltado para pesquisa. A PUC-SP tem esse viés muito forte, é uma formação para a pesquisa. Posteriormente eu fiz a licenciatura. Não havia disciplinas na área de arquivos, mas havia uma formação de conduta ética em relação ao documento. Apresentar documento como parte da discussão e saber contextualizá-lo. Embora não houvesse uma disciplina específica na graduação, havia uma forte formação no sentido ético de trabalhar com os documentos. Mas, na PUC, havia o CEDIC, que tinha um curso de introdução ao tratamento de arquivos. Eu cheguei até a fazer um teste para ser estagiário por lá. Uma coisa que era muito interessante na PUC, era a seguinte: sempre que os estudantes faziam a matéria de Introdução de Pesquisa Histórica, os professores orientavam a fazer a pesquisa no CEDIC. A professora Maria do Rosário da Cunha Peixoto falava dizia o seguinte: "Você vai ser o que você quiser, você vai brilhar, mas agora é hora de mexer em arquivos. Então vai lá no CEDIC". O CEDIC era, e ainda é, muito importante para formação da historiadora e do historiador da PUCSP. E o curso deles também, tanto é que, em 2000, já em março, meu terceiro mês de Arquivo do Estado, me matriculei no curso de Introdução ao Tratamento de Arquivos; foi muito importante para a minha formação e me ajudou a refletir um pouco sobre a minha carreira, porque eu tinha algumas possibilidades: continuar a ser professor, que eu gosto bastante, mas eu não queria ser só isso. Poderia ser professor 


\section{entrevista}

Alexandre de Almeida

universitário, mas naquela época, em 2000, eu nem estava no mestrado ainda. E para a gente, naquela época, o mestrado era algo distante.

Revista Epígrafe: Quais competências você considera essenciais para um documentalista?

Alexandre de Almeida: Quando eu comecei a trabalhar com os arquivos audiovisuais na Fundação FHC, me ocorreu um incômodo. Eu precisava começar a produzir audiovisual porque eu queria ter a mesma experiência da pessoa que fez a filmagem, para entender o que ela está fazendo. É preciso circular. Eu já círculo no meio da música há muito tempo, vou às lojas, na casa de colecionadores, técnicos de áudios, produtores musicais, de músicos, e ali você sempre traz alguma informação. Precisava fazer o mesmo em relação ao audiovisual. A bibliografia produzida pela universidade também é importante, mas, principalmente aquela ideia do Glauber Rocha, "uma câmera na mão, uma ideia na cabeça" é importante para sentir como se produz audiovisual. Ficou ruim? Tudo bem, filma de novo. O importante é você saber por que motivos ficou bom ou ficou ruim. Então eu acho que essa é uma competência importante.

Eu acho também que a conduta ética é muito importante. Trabalhar com documentação exige uma conduta ética muito sólida, porque existe o problema clássico da monumentalização dos documentos, ou seja, hierarquizar os documentos de modo que um se torne mais "importante" que o outro. Como historiador e documentalista, não me cabe fazer juízo de valor sobre qual documento é o mais importante. Se a pessoa acumulou e produziu, tem um sentido para ela. É lógico que existe o procedimento de descarte, mas esse é um procedimento criterioso, e até 


\section{entrevista}

A História - e o arquivo - em versão Punk

"doloroso", porque a gente fica com receio - ou pena - de jogar alguma coisa fora por equívoco.

Eu também acho importante a formação permanente. Conviver com as pessoas que orbitam o gênero documental com o qual você trabalha. Estudar, participar de eventos para troca, e ser generoso. A pessoa acabou de entrar na nossa área e não sabe muito coisa, acho legal dizer a ela "Senta aqui, vamos aprender, vamos estudar, vamos conhecer!" Foi o que foi feito comigo.

Revista Epígrafe: Você trabalha bastante com documentos sonoros e audiovisuais. Quais são as especificidades desses gêneros documentais?

Alexandre de Almeida: Bom, uma dessas especificidades mais óbvias é em relação à linguagem que exige de você outro tipo de conduta diante desse documento. Eu vou dar um exemplo muito prático: nós temos lá na Fundação FHC, na parte de documentação audiovisual, um evento que são os briefings. Basicamente é o encontro do porta-voz da presidência da República com o comitê de imprensa do Palácio do Planalto. Em uma mesma fita VHS temos vários briefings. E aí a gente tem que desenvolver o olhar, para quando mudar de um briefing pro outro, não nos confundir. Como a gente faz isso? Quais são as estratégias que a gente usa para fazer isso? Fica de olho na cor da gravata. Na hora que mudar a cor da gravata, mudou o documento. Ou olhar a cor do paletó. É meio mambembe falar isso, mas não é mambembe, você tem que desenvolver isso. É uma especificidade desse gênero documental.

Há outra questão muito importante que é a preocupação sempre de você transferir essa documentação de suportes; se preocupar com a digitalização; ficar sempre atento à mudança dos leitores, porque chega um momento que você não tem 


\section{entrevista}

Alexandre de Almeida

mais o leitor para aquele formato. Por exemplo, hoje você compra um notebook que não vem com leitor de DVD. O leitor de Blu-ray durou pouquíssimo tempo. Tem outro equipamento, o leitor de MD. O que é isso? Imagina uma fita cassete, mas dentro tem um CDzinho. Ele é regravável... Era muito usado na rádio, quando a gente gravava neles as coletâneas de músicas para tocar ao longo da semana. Então, é preciso ficar atento, em poucos anos eu não tenho mais como ler o que está em determinado formato.

Tem outra que, cada vez mais, me parece importante também, que é em relação à instalação elétrica. Parece estranho falar isso, mas a gente costuma não dar muita atenção se a rede elétrica comporta a quantidade de leitores que nós temos no nosso meio de trabalho. Isso daí pode dar curto-circuito, pode queimar o leitor, gerar incêndio. Isso pode ser algo trivial, mas atrapalha o nosso trabalho.

Outra questão muito importante, é que alguns documentos audiovisuais falando de forma bastante simples para o leigo entender - se parecem com documentos de outros gêneros, mas outros não. Por exemplo, nós temos um discurso do Fernando Henrique Cardoso. Ele está em papel. Mas eu tenho a leitura desse discurso também gravado em vídeo. Se o primeiro documento, em papel, é um discurso, o segundo, em vídeo, também poderia ser chamado de discurso? A resposta é: sim! A diferença é que um faz parte do gênero textual e outro é do gênero audiovisual. Há outros documentos que são específicos do gênero audiovisual e sonoro e que nós precisamos ter o cuidado de identificá-lo da forma mais precisa possível. Foi o meu esforço no doutorado: não chamar tudo de música ou tudo só de canção. As canções têm funções e nós temos que identificá-las. Para quê? Para poder montar um banco de dados com informações mais claras possíveis. 


\section{entrevista}

A História - e o arquivo - em versão Punk

Revista Epígrafe: O uso de documentos não-escritos ainda não é predominante na história. Como usar esses documentos sonoros e audiovisuais como fonte?

Alexandre de Almeida: Bom, eu penso assim: é uma fonte como outra fonte qualquer. O legal deles é que eles vão dialogar com as fontes textuais, por exemplo. Eu trago como exemplo novamente o meu doutoramento. Aquela canção só me permitiu batizá-la com o nome "canção de denúncia" porque eu há uma série de documentos escritos que diziam o mesmo que a canção dizia. Estou me referindo lá ao "mito da conspiração judaica".

Não só para esses grupos, mas para vender um produto, divulgar uma candidatura, divulgar um evento, uma campanha educativa... Os recursos audiovisuais e sonoros são cada vez mais recorrentes, porque hoje muita gente tem celular, tem acesso à internet, consome Instagram, consome Facebook, consome YouTube e boa parte dessas campanhas são feitas nessas plataformas. Por quê? Porque são fáceis de transmitir, porque elas possibilitam atingir um público maior, até o público que não sabe ler. Então precisamos nos familiarizar com as novas tecnologias e plataformas, pois a tendência é os documentos audiovisuais e sonoros ocuparem mais espaço na pesquisa acadêmica, como próprio momento que nós vivemos agora. Nós vemos uma profusão de entrevistas, debates, situações do cotidiano, vídeos de gatinhos fofos, etc... Tudo em linguagem audiovisual.

Acho muito importante os documentos audiovisuais e sonoros para a gente compreender a vida cotidiana nesse momento de quarentena, porque há as pessoas que escrevem e há as pessoas que filmam, em situações muito bonitas, como a gente pode ver, por exemplo, aqueles corais na Itália, na Espanha, de pessoas cantando como forma de apoiarem-se mutuamente, porque estão presas na quarentena, ou situações mais trágicas, como imagens em meio a algum combate na Síria ou nos 


\section{entrevista}

Alexandre de Almeida

subúrbios brasileiros. Nós temos os documentos audiovisuais tratando de política brasileira, como os panelaços, por exemplo, que são um momento de insatisfação popular e que são gravados por pessoas que estão em seus apartamentos. Nós temos o uso do vídeo e do som para denunciar pessoas que estão burlando a quarentena e para se comunicar com os entes queridos. Então acho que dentro das possibilidades de uso desses documentos como fontes, o audiovisual e o sonoro serão gêneros documentais muito importantes para a gente ver e compreender a vida cotidiana durante a quarentena.

Revista Epígrafe: Você poderia nos descrever como é o cotidiano de trabalho em um arquivo?

Alexandre de Almeida: Bom, vou contar a partir da experiência na Fundação FHC. O que eu faço lá na Fundação? Basicamente coordeno o trabalho com documentação audiovisual e sonora e ele se divide em algumas atividades. Uma delas é a atividade descrição documental. Vou relatar uma dessas experiências. Nós tínhamos vários CDs com notícias que pertenciam ao acervo do Sérgio Motta, o ex-ministro das comunicações. O que nós fizemos? Num primeiro momento, nós abrimos uma ficha para cada CD. A gente verificou que isso poderia ser uma ação que dificultaria a pesquisa, então o que nós fizemos? Nós fizemos a edição notícia a notícia, ou seja, cortamos todas as notícias em um editor de vídeo, e identificamos uma a uma de acordo com o seu contexto, de modo que agora você entra no banco de dados, e quando vai pesquisar notícias que estão presentes no acervo do Sérgio Motta, você vai encontrar com muita facilidade notícias organizadas por seus eventos geradores, como privatizações, polêmicas nas quais eles se envolveu, aniversários, etc. Então essa é uma linha do meu trabalho, a inserção de documentos, sempre com a 


\section{entrevista}

A História - e o arquivo - em versão Punk

preocupação de oferecer o máximo possível de informação presente no documento ao consulente, e sem cair na tentação do "eu acho", que a gente pode até relembrar a questão da conduta, né. "Eu acho que o documento significa isso". A gente não acha nada. O documento está ali, e está nos informando. Em um trabalho posterior, de uma análise, de interpretação daqueles documentos, você procede da maneira que Ihe convier e parecer melhor, de acordo com sua proposta teórica, mas o nosso trabalho, que muitas vezes é tratado como "mecânico", é um trabalho muito importante, para oferecer a informação ao consulente de maneira que o ajude na pesquisa da maneira mais eficaz possível e sem fugir do que o documento nos diz.

O outro trabalho é a discussão metodológica. Todos nós participamos de reuniões relacionadas ao vocabulário controlado usado na descrição de documentos, funcionalidades do banco de dados e identificação de novos documentos. Então, por exemplo, nós trabalhamos muito com as descrições dos contextos dos documentos e, como falei em relação às notícias, nós usamos o mesmo tipo de evento para todos os gêneros documentais. Vou usar como exemplo o evento "inauguração". Uma inauguração pode ser fotografada, filmada, produz rascunhos de discurso, uma notícia na imprensa e pode até mesmo aparecer no acervo um presente que a pessoa ganhou nesse evento. Então nós precisamos discutir com muito cuidado se o termo "inauguração" será a palavra mais adequada para gente utilizar em todos os registros - ou "fichas descritivas" - dos diversos gêneros documentais, de modo que, quando o consulente vai até o banco de dados e escolhe o tipo de evento "inauguração" ele vai ter acesso aos diversos conjuntos de documentos sobre cerimônias de inauguração de uma estrada, uma hidrelétrica, uma escola, etc.. Então as reuniões metodológicas são parte fundamental do nosso trabalho. É uma preocupação muito grande nossa não criar critérios a priori. Isso também é algo que pode atrapalhar muito no processo de identificação dos documentos e eventos. 


\section{entrevista}

Alexandre de Almeida

Outro trabalho que também faz parte do meu cotidiano é a difusão do nosso acervo. Nós temos o Portal do Acervo, onde você encontra os documentos que já foram tratados. E nós temos algumas redes sociais, como Instagram, como YouTube, em que nós divulgamos o nosso trabalho, nosso cotidiano, divulgamos documentos do acervo, divulgamos atividades de outras instituições na forma do repost. Outra atividade de difusão é a produção de exposições. Recentemente, nós montamos uma exposição interna na Fundação FHC sobre os diversos acervos sob a nossa guarda e o audiovisual entrou com uma seleção de comerciais na área de educação, do tipo: "Xuxa convidando as pessoas para fazer o Enem" e comerciais do programa Comunidade Solidária. E agora nós estamos desenvolvendo uma próxima exposição que será bem interessante que envolve o audiovisual e as caricaturas. É uma discussão na nossa área sobre a dificuldade de você identificar contexto de caricaturas ou de charges. Nós estamos conseguindo agora encontrar as notícias, os pronunciamentos, entrevistas ou os discursos de FHC na época como ministro da economia e como isso foi retratado nessas charges. Então brevemente teremos aí uma exposição na internet - spoiler! -, que também é um trabalho de historiador. A importância da gente no arquivo é essa: o arquivo não é o espaço apenas para uma profissão, é o espaço de todas as profissões; como eu falei anteriormente, a gente precisa de uma formação multifacetada para trabalhar nos arquivos. E a nossa grande contribuição como historiador e como historiadora é a capacidade de identificar o contexto dos documentos para não oferecer uma descrição anacrônica, para não oferecer uma descrição que não monumentalize os documentos.

Revista Epígrafe: Pensando nisso que você acabou de falar, trabalhar em arquivo fez você repensar sua atividade como historiador? 


\section{entrevista}

A História - e o arquivo - em versão Punk

Alexandre de Almeida: Todo dia! Eu penso cada vez mais a minha satisfação como historiador. Aliás, um ato heroico no Brasil, né? Não só pela questão de oportunidade de emprego, grana, mas a questão do próprio reconhecimento da profissão. Mas isso me faz desistir da profissão, me desestimula? Confesso que às vezes sim. Às vezes você fica meio pensativo, "poxa, será que eu deveria ter feito veterinária?". Mas aí deixo isso de lado e fico muito animado toda vez em que eu vejo um documento lá na Fundação FHC ou mesmo aqui em casa - estou organizando meus acervos aqui para criar um centro de documentação sobre a direita radical e extrema direita.

A gente vai criando uma nova cultura em relação à importância dos documentos no debate cotidiano sobre qualquer tema, por exemplo, como lidar com as fakenews, que se tornou uma bandeira diária de quem trabalha com documentação. Certamente, vocês já tiveram debates familiares, com amigos mais próximos, alguém que não tem essa familiaridade que nós temos na lida com documento e de perguntar se é verdade ou se é mentira. Eu recebo da minha mãe uma notícia e a pergunta sobre o que eu acho. As minhas tias perguntam: “Ah! É verdade que se injetar desinfetante no sangue vai matar o coronavírus?". Aí, eu respondo "ah, não sei, quem falou mostrou alguma prova, algum estudo científico que comprova isso?", "Não mostrou.", "Então não acredita, só acredita se ele mostrar e você ler e entender o que ele disse". Então, me faz pensar nisso, a gente não tem que ficar só do "lado de cá" do muro da universidade. A gente tem que pular esse muro, depois volta um pouquinho, pula de novo, ou fazer uma porta, um buraco nesse muro, porque às vezes a gente acha que o mundo da História está só na Universidade.

Revista Epígrafe: Eu queria que você falasse um pouco sobre a digitalização. Eu vejo que é algo mal discutido, nessa questão de "vamos sair digitalizando tudo" contra 


\section{entrevista|}

Alexandre de Almeida

“não vamos digitalizar nada, vamos deixar tudo em papel". Queria que você falasse um pouco disso.

Alexandre de Almeida: Essa discussão sobre digitalização, eu tive a oportunidade de pegá-la mais ou menos no começo. Quando se começa a falar nisso com mais ênfase é no final dos anos 1980, quando se começa a se perceber que é preciso preservar os documentos porque eles estão se deteriorando.

A primeira coisa é você ter um local de guarda adequado para preservar o documento, sempre com as melhores práticas, mas nem sempre temos espaço, ainda mais espaço adequado. Digitalizar não significa jogar fora depois. Isso é um senso comum que está se criando, ganhando força. Nós temos um senso comum de que a solução para a crise de espaço é a digitalização. Também é preciso discutir sobre a autenticidade e a garantia de que os documentos digitalizados são verídicos. Por outro lado, há outra discussão que é inevitável, o mundo digital está aí. A gente brinca no trabalho com a seguinte ideia: se você tem conta numa fintech, por exemplo, quem que é o arquivista que guarda, que cuida dessa documentação? É um robô. São algoritmos que estão cuidando, entre muitas aspas, dos meus documentos. Isso para mim é bom, porque eu não quero me deslocar até o consultório médico para pegar uma guia de exame ou ver meu prontuário médico. Então, nós temos dois contextos para debater. As facilidades do mundo digital e o compromisso de guardar os documentos físicos, porque digitalizar não significa uma carta branca para se jogar tudo fora.

Qual é o meio termo disso? Ainda estamos em discussão. Uma ideia na nossa área, consolidada há algum tempo, é que é muito importante digitalizar para garantir o acesso e não digitalizar para preservar. Para quê? Para não abrir o precedente de jogar tudo fora. Além disso, o decreto assinado no ano passado pelo governador do 


\section{entrevista}

A História - e o arquivo - em versão Punk

Estado de São Paulo, criando o programa "São Paulo Sem Papel", é mais um ponto de pressão para a realização da digitalização, que pode gerar outro problema: a inviabilidade de encontrar informações. Portanto, digitalização deve ser realizada junto com a produção de metodologias de organização e recuperação eficientes das informações.

Bom, minha posição é a seguinte: para os documentos audiovisuais e sonoros, essa transposição de formatos e suportes é crucial. Eu não vou ter no meu acervo um gravador de rolo à disposição do consulente. Então, digitalizar para o acesso é importante, para a preservação é uma discussão já encaminhada, mas que precisa ser enfrentada.

Revista Epígrafe: Que dicas você daria para um estudante de História que gostaria de entrar para essa área de trabalho?

Alexandre de Almeida: Bom, a primeira delas é procurar estágio. Fazer o máximo de estágios possíveis que aparecerem. Pela minha própria experiência, existe o elemento do recurso financeiro, mas tente circular o máximo possível. Hoje eu estou em uma situação muito mais tranquila em comparação aos anos 1990, graças a Deus, mas foi uma opção. Bem, meu caso foi uma opção de quem não tinha muita opção... [risos]. Então a primeira dica talvez seja essa, fazer estágio.

Participar o máximo possível dos eventos que ocorrem nas instituições. A gente vê cada vez mais uma profusão de eventos via internet, não só por conta agora da pandemia, provavelmente isso se torne uma constante. Se possível também, conversar com as instituições e fazer visitas técnicas, que são muito importantes. Se não der para fazer sozinho porque é estudante e às vezes a instituição no seu dia a 


\section{entrevista}

Alexandre de Almeida

dia não tem condições de atender às pessoas, de repente propor a algum professor de alguma disciplina que agende uma visita técnica.

Consumir a literatura existente. O site da ARQ-SP, por exemplo, tem muito material para download. Mas há muitas outras instituições de arquivistas e de profissionais da área audiovisual e sonora produzindo literatura sobre o assunto, vale a pena também acompanhar isso. E pela minha experiência pessoal, no caso de arquivos audiovisuais e sonoros, se curte essa documentação, aprender como fazer. Acho que é uma experiência bem bacana, você fica muito familiarizado, não só com os jargões, mas também com os processos, com as tecnologias. Como eu falei, eu tenho muita amizade nessa área de audiovisual e de som e muitas vezes eles me perguntam como fazer ou o que fazer. $E$, às vezes, eles me dão soluções muito simples. Vou dar um exemplo muito prático: estava mexendo com uma documentação que está em fita cassete, eu desmonto a fita, enfim, faço a higienização dela e fiquei na dúvida sobre qual seria o melhor produto para lavar a embalagem, aquela caixinha plástica que vocês conhecem. E aí, conversando com um amigo meu, dono de uma loja de equipamentos audiovisuais, ele falou: "você abra a torneira, pega uma buchinha amarela, detergente neutro e lava. Se não tiver nada na embalagem, nenhuma etiqueta, só a caixinha mesmo, você lava.". Tá aí, essas pessoas têm muita experiência nessa área, porque durante muito tempo, especialmente com o advento do CD, essas mídias analógicas foram colocadas de lado, mas elas mantêm ainda uma legião de fanáticos, de audiófilos, e muitos deles aprenderam uma série de soluções na área de conservação, preservação, na área de reprodução, digitalização, que estão muito à frente de discussões que fazemos na nossa área. Então é uma galera que vale a pena ser ouvida e nós também, certamente, repito, temos muito a oferecer a eles. 


\section{entrevista}

A História - e o arquivo - em versão Punk

Por fim, enfatizo: circule! Circule por todas as áreas do conhecimento o máximo possível. Pule os muros da Universidade quantas vezes forem necessárias. E, ah, como se diz no Escotismo: “Esteja preparado!". 